\title{
Bioassay-guided evaluation of central nervous system effects of citronellal in rodents
}

\author{
Mônica S. Melo, ${ }^{1}$ Marilia T. de Santana, ${ }^{1}$ Adriana G. \\ Guimarães, ${ }^{1}$ Rosana S. Siqueira, ${ }^{1}$ Damião P. De Sousa, ${ }^{1}$ Márcio \\ R. V. Santos, ${ }^{1}$ Leonardo R. Bonjardim, ${ }^{1}$ Adriano A. S. Araújo, ${ }^{1}$ \\ Alexandre S. C. Onofre, ${ }^{1}$ Julianeli T. Lima, ${ }^{2}$ Jackson R. G. S. \\ Almeida, ${ }^{2}$ Lucindo J. Quintans-Júnior ${ }^{*}, 1$
}

${ }^{1}$ Departamento de Fisiologia, Universidade Federal de Sergipe, Brazil,

${ }^{2}$ Colegiado de Ciências Farmacêuticas, Núcleo de Estudos e Pesquisas de Plantas

Medicinais, Universidade Federal do Vale do São Francisco, Brazil.
Revista Brasileira de Farmacognosia Brazilian Journal of Pharmacognosy 21(4): 697-703, Jul./Aug. 2011

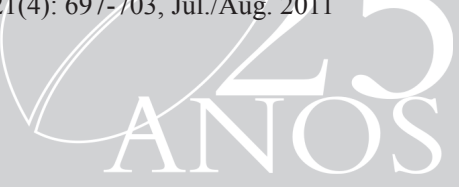

Article

Received 31 Jul 2010

Accepted 20 Dec 2010 Available online 8 Jul 2011

Keywords: anticonvulsant activity citronellal depressant activity monoterpenes

ISSN $0102-695 \mathrm{X}$ doi: 10.1590/S0102-695X2011005000124

\section{Introduction}

Numerous herbal medicines are recognized to have activity on the central nervous system (CNS), and they have at least a hypothetical potential to affect chronic conditions, such as anxiety, depression, headaches or epilepsy, which do not respond well to conventional treatments (Carlini, 2003). An increasing number of studies have demonstrated that essential oils derived from plants exhibit a variety of biological properties, such as anticonvulsant (Quintans-Júnior et al., 2008a), analgesic (Almeida et al., 2001) and Central Nervous System (CNS) activities (Carlini, 2003; Silva et al., 2007). Monoterpenes are the primary components of essential oils and the effects of many herbal medicines have been attributed to them (Gherlardini et al., 2001; De Sousa et al., 2006).

Currently, several monoterpenes have been reported to have neuroactive properties. Their actions in experimental animal models have been mainly linked to protection against pain (Guimarães et al., 2010; Quintans-Júnior et al., 2010a), anxiety (Silva et al., 2007), insomnia (Buchbauer et al.,
1992) and convulsion (De Sousa et al., 2006, 2007; Silva et al., 2009). Therefore, citronellal (CT) (1) is a monoterpene, predominantly formed by the secondary metabolism of plants. It is typically isolated as a non-racemic mixture of its $R$ and $S$ enantiomers by steam distillation or solvent extraction from the oils of Corymbia citriodora Hill and Johnson (former Eucalyptus citriodora Hook) Cymbopogon nardus and $C$. winterianus (Lenardão et al., 2007). Recently, in a preliminary behavioral screening realized with the essential oil of the $C$. winterianus, our group demonstrates CNS depressant and anticonvulsant activities in rodents (QuintansJúnior et al., 2008b). Melo et al., (2010) and Quintans-Júnior et al., (2010a, 2011) demonstrated an antinociceptive effect of the CT using unspecific and specific tests.

$\mathrm{CT}$ is one of the major components of essential oil of the $C$. winterianus and the role of CT in CNS property is not yet well established. In consequence of it, we decided to assess the CNS effects of this compound in rodents. 


\section{Materials and Methods}

Drugs

The drugs used were: pentylenetetrazole (PTZ), picrotoxin (PIC), phenytoin (PHE), polyoxyethylenesorbitan monolated (Tween 80) purchased by Sigma (USA) and diazepam (DZP) by Cristália (Brazil). The citronellal (1) used was a racemic mixture of $R$ and $S$ enantiomers [(RS)- $( \pm)$-citronellal] (Dierberger, Brazil) with 98\% purity. PTZ, PIC, PHE, DZP and CT were administrated by intraperitoneally route (i.p.) at a dose volume of $0.1 \mathrm{~mL} / 10 \mathrm{~g}$.<smiles>CC(C)=CCC[C@H](C)CC=O</smiles>

$(R)-1$

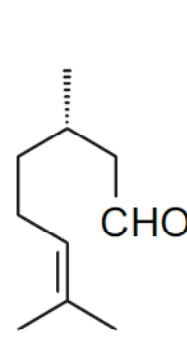

(S)-1
Animals

Male Swiss mice (30-35 g), 2-3 months of age, were used throughout this study. The animals were randomly housed in appropriate cages at $25 \pm 2{ }^{\circ} \mathrm{C}$ on a $12 \mathrm{~h}$ light/dark cycle (lights on 6:00-18:00 h) with free access to food (Purina ${ }^{\circledR}$ ) and water. All experiments were carried out between 9:00 and 16:00 h in a quiet room. Experimental protocols and procedures were approved by the Animal Care and Use Committee at the Federal University of Sergipe (CEPA/UFS \# 12/08).

\section{Behavioral effects}

Behavioral screening of the mice $(n=6$, per group) was performed following parameters described by Almeida et al., (1999) and animals were observed at $0.5,1,2$ and $4 \mathrm{~h}$ after intraperitoneal (i.p.) administration of CT $(100,200$ and $400 \mathrm{mg} / \mathrm{kg}$, i.p. $)$.

\section{Locomotor activity}

Mice were divided into four groups of eight animals each. Vehicle (saline/Tween $800.2 \%$; control group) and $\mathrm{CT}(100,200$ and $400 \mathrm{mg} / \mathrm{kg}$, i.p.) were injected. The spontaneous locomotor activity of the animals was assessed in a cage activity $(50 \times 50 \times 50$ $\mathrm{cm}$ ) in $0.5,1$ and $2 \mathrm{~h}$ after administration (Asakura et al., 1993).

\section{Motor coordination test (Rota-rod test)}

A Rota-rod tread mill device (AVS ${ }^{\circledR}$, Brazil) was used for the evaluation of motor coordination (Perez et al., 1998). Initially, the capable mice to remain on the Rota-rod apparatus longer than $180 \mathrm{~s}$ (9 rpm) were selected $24 \mathrm{~h}$ before the test. Thirty minutes after the administration of either CT (100, 200 and $400 \mathrm{mg} /$ $\mathrm{kg}$, i.p.), vehicle (saline/Tween 80 0.2\%; control group) or DZP $(1.5 \mathrm{mg} / \mathrm{kg}, i . p$.), each animal was tested on the Rota-rod apparatus and the time ( $\mathrm{s}$ ) remained on the bar for up to $180 \mathrm{~s}$ was recorded after $0.5,1$ and $2 \mathrm{~h}$.

\section{Pentylenetetrazole (PTZ)-induced convulsions}

PTZ was used to induce clonic convulsions (Smith et al., 2007). Mice were divided into five groups ( $n=8$, per group). The first group served as control and received vehicle (Tween $800.2 \%$ in distilled water, the solvent for CT), while the second group was treated with DZP (2 $\mathrm{mg} / \mathrm{kg}$, i.p.). The remaining groups received an injection of $\mathrm{CT}(100,200$ and $400 \mathrm{mg} /$ $\mathrm{kg}$, i.p.). After $0.5 \mathrm{~h}$ of drug administration, the mice were treated with PTZ (i.p.) at a dose of $60 \mathrm{mg} / \mathrm{kg}$. The latency and percent of inhibition clonic convulsions were registered. The incidence of deaths was noted until $48 \mathrm{~h}$ after the injection of PTZ.

\section{Effects of flumazenil on PTZ-induced convulsion}

The effect of selective $\mathrm{GABA}_{\mathrm{A}}-\mathrm{BZD}$ receptor antagonist, flumazenil (FLU) (File \& Pellow, 1986), on the anticonvulsant activity of CT was investigated. This protocol was performed according to QuintansJúnior et al. (2010b). In the experimental groups, mice were given FLU (10 mg/kg, i.p.) $20 \mathrm{~min}$ before the administration of CT $(400 \mathrm{mg} / \mathrm{kg}, i . p),. 0.5 \mathrm{~h}$ before the injection of PTZ. In the standard group, the animals received FLU $20 \mathrm{~min}$ before the administration of DZP ( $2 \mathrm{mg} / \mathrm{kg}$, i.p.) ( $0.5 \mathrm{~h}$ before the injection of PTZ) (Quintans-Júnior et al., 2010b). The anticonvulsant activity of CT and DZP in mice pretreated with FLU was assessed.

\section{Picrotoxin (PIC)-induced convulsion}

The method has been described previously (Lehmann et al., 1988; Ngo Bum et al., 2001). Animals were divided into five groups $(n=8$, per group). The control group received vehicle and standard group was treated with DZP (2 mg/kg, i.p.). The remaining groups were treated with 100,200 and $400 \mathrm{mg} / \mathrm{kg}$ of CT (i.p.). After $0.5 \mathrm{~h}$ of drug administration, the mice were treated with PIC at a dose of $8 \mathrm{mg} / \mathrm{kg}$ (i.p.). Immediately after the injection of the convulsant, mice were individually 
placed in plastic boxes and observed for the time onset of clonic convulsion (latency), percent clonic convulsion and deaths. The incidence of deaths was noted until $48 \mathrm{~h}$ after the injection of PIC.

\section{Maximal electroshock (MES) test}

MES produces reproducible tonic convulsions characterized by tonic hindlimb extension (THE) (Oliveira et al., 2001). In this experiment, electroconvulsive shock $(130 \mathrm{~V}, 150 \mathrm{pulses} / \mathrm{s}, 0.5$ s) was delivered through auricular electrodes (ECT UNIT 7801- Ugo Basile) to induced THE. Mice were divided into five groups $(n=10$, per group). The first group served as control and received vehicle, while the second group was treated with PHE $(25 \mathrm{mg} / \mathrm{kg}$, i.p.). The others groups received an injection of $\mathrm{CT}$, similarly before experiment. After $0.5 \mathrm{~h}$ all groups received electroconvulsive shock. The animals that did not exhibit THE were considered protected (Tortoriello \& Ortega, 1993).

\section{Statistical analysis}

The data obtained were evaluated by one-way analysis of variance (ANOVA) followed by Dunnett's test. The incidence (\%) of clonic or tonic-clonic convulsions as well as the mortality were evaluated by Fisher's Exact Test. Differences were considered to be statistically significant when $p<0.05$.

\section{Results}

Behavioral effects
CT at doses of 100, 200 and $400 \mathrm{mg} / \mathrm{kg}$ (i.p.) revealed behavioral changes in animals $0.5,1,2$ and $4 \mathrm{~h}$ after treatment: decrease of spontaneous activity, palpebral ptosis, ataxia, analgesia, and sedation. Behavioral changes were more evident in the first $2 \mathrm{~h}$. These effects were dose-dependent.

\section{Locomotor activity}

In doses of 100,200 or $400 \mathrm{mg} / \mathrm{kg}, \mathrm{CT}$ caused a significant decrease of ambulation (number of crossings) at $0.5,1$ and $2 \mathrm{~h}$ after administration (Figure $1)$.

\section{Motor coordination (Rota-rod test)}

In this test, 0.5 and $1 \mathrm{~h}$ after administration of $\mathrm{CT}$, only at the dose of $400 \mathrm{mg} / \mathrm{kg}$ (i.p.) the remaining time of animals on the Rota-rod apparatus was significantly reduced (Figure 2).

\section{Anticonvulsant activity}

Table 1 shows that in the control group the PTZ consistently induced clonic convulsions in $100 \%$ of mice. CT $(100,200$ and $400 \mathrm{mg} / \mathrm{kg}$, i.p.) delayed the onset of PTZ-induced tonic convulsion significantly. CT $(400 \mathrm{mg} / \mathrm{kg}$, i.p. $)$ protected $80 \%(p<0.001)$ of mice against the convulsion. DZP ( $2 \mathrm{mg} / \mathrm{kg}$, i.p.) completely protected the animals against the tonic convulsion elicited by PTZ.

As can be seen in Table 1, the administration of FLU (10 mg/kg, i.p.) antagonized the effect of CT (400 $\mathrm{mg} / \mathrm{kg}$, i.p. $)$ and DZP (2 mg/kg, i.p. $)$ in the prolongation of convulsion latency.

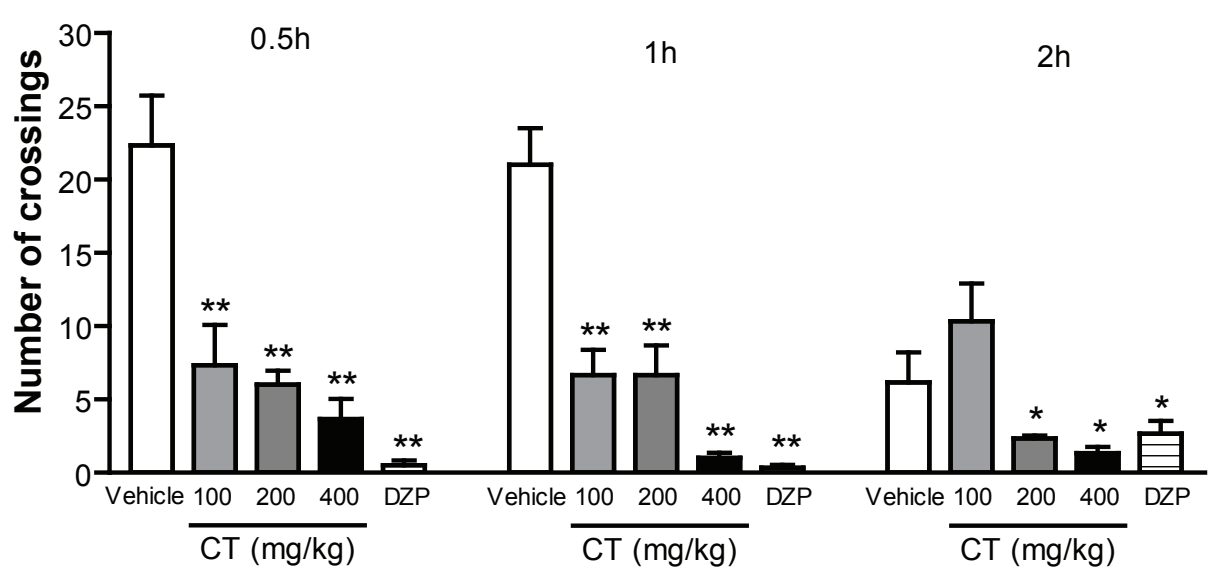

Figure 1. Effect of citronellal (CT, 100, 200 and $400 \mathrm{mg} / \mathrm{kg}$, i.p.) or diazepam (DZP, $1.5 \mathrm{mg} / \mathrm{kg}$, i.p.) on locomotor activity of mice. The parameters evaluated were the total number of pulses of crossings in activity cage. Values are the mean \pm SEM for eight mice (per group). ${ }^{*} p<0.05$ or ${ }^{* *} p<0.001$ as compared to control (vehicle), one way ANOVA followed by Dunnet's test. 


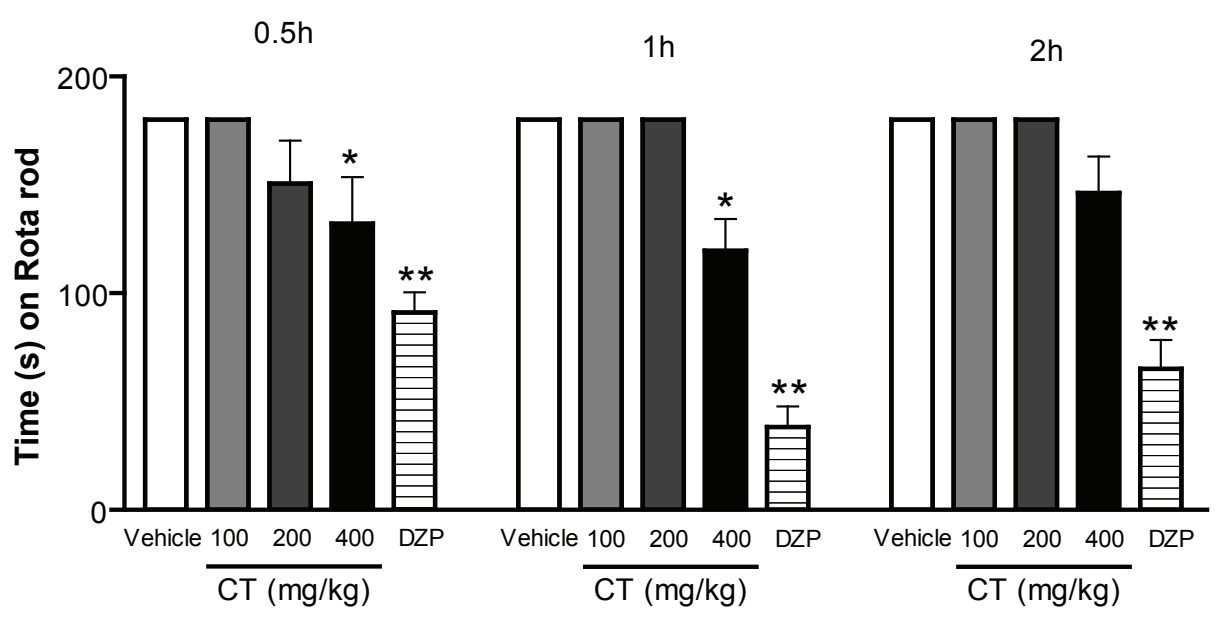

Figure 2. Time (s) on the Rota-rod observed in mice after i.p. treatment with vehicle (control), citronellal (CT, 100,200 and 400 $\mathrm{mg} / \mathrm{kg}$, i.p.) or diazepam (DZP, $1.5 \mathrm{mg} / \mathrm{kg}$, i.p.). The motor response was recorded for the following $180 \mathrm{~s}$ after drug treatment. Values are the mean \pm SEM for eight mice (per group). ${ }^{*} p<0.05$ or $* * p<0.001$ as compared to control (vehicle), one way ANOVA followed by Dunnet's test.

Table 1. Effect of citronellal (CT) on PTZ-induced convulsion in mice.

\begin{tabular}{lcccc}
\hline Treatment & $\begin{array}{c}\text { Dose } \\
(\mathrm{mg} / \mathrm{kg})\end{array}$ & Latency $(\mathrm{s})^{\mathrm{a}}$ & $\begin{array}{c}\text { \% Inhibition } \\
\text { of convulsion }\end{array}$ & $\begin{array}{c}\text { \% Inhibition } \\
\text { of death }\end{array}$ \\
\hline Vehicle & - & $126.3 \pm 11.9$ & 0 & 0 \\
$\mathrm{CT}$ & 100 & $329.0 \pm 122.6^{\mathrm{d}}$ & 0 & 0 \\
$\mathrm{CT}$ & 200 & $575.8 \pm 88.0^{\mathrm{e}}$ & 20 & $40^{\mathrm{b}}$ \\
$\mathrm{CT}$ & 400 & $852.5 \pm 47.5^{\mathrm{f}}$ & $80 \mathrm{c}$ & 0 \\
$\mathrm{CT}+\mathrm{FLU}$ & $400+10$ & $141.8+38.9$ & 0 & 20 \\
DZP & 2 & $900.0 \pm 0.0^{\mathrm{f}}$ & $100 \mathrm{c}$ & $100^{\mathrm{c}}$ \\
DZP+FLU & $2+10$ & $131.2+25.2$ & 0 & 10
\end{tabular}

$n=8 ;$ a Values represent mean \pm SEM; ${ }^{b} p<0.05$ (Fisher`s test), significantly different from control; ${ }^{c} p<0.001$ (Fisher`s test), significantly different from control; ${ }^{\mathrm{d}} p<0.05$ (one-way ANOVA and Dunnett`s test), significantly different from control; ${ }^{\mathrm{e}} p<0.01$ (one-way ANOVA and Dunnett's test), significantly different from control; ${ }^{\mathrm{f}} p<0.001$ (one-way ANOVA and Dunnett's test), significantly different from control.

When given i.p. only the highest dose of CT $(400 \mathrm{mg} / \mathrm{kg}$, i.p.) increased the latency for convulsions induced by PIC, significantly different from control $(p<0.001)$ (Table 2).

On MES-induced convulsion, CT (200 and 400 $\mathrm{mg} / \mathrm{kg}$, i.p.) was effective to reduce the occurrence of tonic convulsion in 30 and $40 \%$ of animals, respectively (Figure 3).

\section{Discussion}

In the present study, the CNS depressant and anticonvulsant activities of $\mathrm{CT}$ were investigated in different animal models. Initially, to assess the behavioral effects, the mice were treated with different doses of CT $(100,200$ and $400 \mathrm{mg} / \mathrm{kg}$, i.p. $)$ and presented alterations, such as reduction of the ambulation, palpebral ptosis, ataxia and sedation. These behavioral changes suggest a possible effect on CNS and are similar to drugs that reduce the CNS activity (Morais et al., 2004; Netto et al., 2009).

Table 2. Effect of citronellal (CT) on PIC-induced convulsion in mice.

\begin{tabular}{lcccc}
\hline Treatment & $\begin{array}{c}\text { Dose } \\
(\mathrm{mg} / \mathrm{kg})\end{array}$ & ${\text { Latency }(\mathrm{s})^{\mathrm{a}}}^{\mathrm{O}}$ & $\begin{array}{c}\text { \% Inhibition } \\
\text { of convulsion }\end{array}$ & $\begin{array}{c}\text { \% Inhibition } \\
\text { of death }^{2}\end{array}$ \\
\hline Vehicle & - & $496.2 \pm 24.5$ & 0 & 0 \\
DZP & 2 & $1200.0 \pm 0.0^{\mathrm{b}}$ & $100^{\mathrm{d}}$ & $100^{\mathrm{d}}$ \\
$\mathrm{CT}$ & 100 & $498.5 \pm 21.01$ & 0 & 0 \\
$\mathrm{CT}$ & 200 & $567.5 \pm 45.9$ & 20 & 20 \\
$\mathrm{CT}$ & 400 & $1163.7 \pm 19.3^{\mathrm{b}}$ & $50^{\mathrm{c}}$ & $40^{\mathrm{c}}$ \\
DZP & 2 & $900.0 \pm 0.0^{\mathrm{f}}$ & $100^{\mathrm{c}}$ & $100^{\mathrm{c}}$ \\
DZP+FLU & $2+10$ & $131.2+25.2$ & 0 & 10 \\
\hline
\end{tabular}

$n=8$; aValues represent mean \pm SEM; ${ }^{b} p<0.001$ (one-way ANOVA and Dunnett's test), significantly different from control; ${ }^{c} p<0.01$ (Fisher's test), significantly different from control; ${ }^{\mathrm{d}} p<0.001$ (Fisher`s test), significantly different from control.

$\mathrm{CT}$ at all doses caused a significant reduction of ambulation of animals in the test of spontaneous movement after $0.5,1$ and $1.5 \mathrm{~h}$ of its administration in the doses of 100,200 and $400 \mathrm{mg} / \mathrm{kg}$, that corroborates with the hypothesis of the CT reduces the CNS activity. It was reported that reduction of the ambulation of the animals is characteristic of psychopharmacological drugs (Leite et al., 2008; Carlini, 2003).

The reduction of the locomotor activity was observed by many monoterpenes (Passos et al., 2009) and it can be due to either through an inhibitory effect of the CT in CNS or by muscular relaxant activity in the 
periphery. We suggest that CT could possess a neurosedative activity or a profile for hypnotic drug (Carlini, 2003).

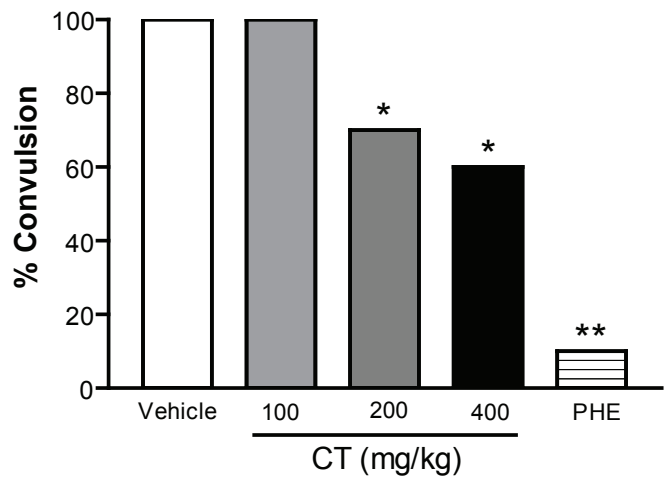

Figure 3. Effect of citronellal (CT, 100, 200 and $400 \mathrm{mg} / \mathrm{kg}$, i.p.) or phenytoin (PHE, $25 \mathrm{mg} / \mathrm{kg}$, i.p.) on the convulsion induced in Maximal Electroshock test (MES). Data are reported in percent of convulsion vs control (vehicle). $* p<0.05$ or $* * p<0.001$ as compared to control (vehicle), ANOVA followed by Fisher's test.

In this context, to assess whether the CT produces loss of motor coordination of animals was performed to Rota-rod apparatus. This result was not corroborated by Melo et al. (2010), which did not find changes in motor coordination. However, in the present study, it was conducted with different parameters (9 rpm and for a period of $180 \mathrm{~s}$ of observation), which may explain this difference. Thus, the lack of motor coordination in the test of the Rota-rod is characteristic of a drug that reduces the CNS activity, such as anxiolytics, sedatives and hypnotics (Almeida et al., 1999; Olayiwola et al., 2007).

PTZ is considered an experimental model for the "convulsive crises generalized of the clonic type" (Oliveira et al., 2001). PTZ has been reported to produce convulsion by inhibiting $\gamma$-aminobutyric acid (GABA) neurotransmission (Löscher \& Schmidt, 2006). GABA is the main inhibitory neurotransmitter substance in the brain, and is widely implicated in epilepsy. Enhancement of GABAergic neurotransmission has been shown to inhibit or attenuate convulsion, while its inhibition or activity is known to promote and facilitate convulsion (Smith et al., 2007). However, antagonism of PTZ-induced convulsion suggests that the CT might have effects on GABAergic neurotransmission.

In order to determine the role of BZD receptors participation in the CT-induced anticonvulsant effects, flumazenil (FLU), a specific antagonist of the benzodiazepine site in the GABA-benzodiazepine receptor complex, was used (File \& Pellow, 1986). The results obtained from PTZ-induced convulsion model in mice pretreated with FLU, suggest that CT could facilitate the inhibitory activity of the GABAergic system, probably through a competitive agonist action in the BZD site of the GABA receptors. The significantly effect on the motor coordination, on high doses, might support this theory, as GABAergic drugs usually are sedative (Pedersen et al., 2009).

According to Nicoll (2001), PIC, a GABA ${ }^{-}$ receptor antagonist, produces seizures by blocking the chloride-ion channels linked to GABA -receptors, thus preventing the entry of chloride ions into the brain and, consequently, inhibitory transmission in the brain (Löscher \& Schmidt, 2006). Therefore, the findings of the present study suggest that CT $(400 \mathrm{mg} / \mathrm{kg}$, i.p. $)$ might have inhibited and/or attenuated the PIC-induced convulsions of mice by interfering with GABAergic neurotransmission (Oliveira et al., 2001).

MES test is the most frequently used as an animal model for identification of anticonvulsant activity of drugs for the "grand mal" (Oliveira et al., 2001; Smith et al., 2007). All the currently available antiepileptic drugs (AEDs), which are clinically effective in the treatment of generalized tonic-clonic convulsions, such as phenobarbital, lamotrigine and carbamazepine, are effective in the MES test (Löscher, 1998). Our results suggest that CT (in high doses) may prove to be important chemical leads for future antiepileptic drugs.

In conclusion, the results suggest a possible depressant CNS and anticonvulsant effects of CT. The precise mechanisms of possible behavioral effects of CT are not clear. However, GABAergic neurotransmitter system might be involved. Nevertheless, more studies will be required for elucidation this effect and neuronal mechanisms relationship.

\section{Acknowledgment}

This work was supported by grant from the Research Supporting Foundation of State of Sergipe (Fundação de Amparo à Pesquisa do Estado de Sergipe) [grant number 019.203.00860/2009-6].

\section{References}

Almeida RN, Falcão ACGM, Diniz RST, Quintans-Júnior LJ, Polari RM, Barbosa-Filho JM, Agra MF, Duarte JC, Ferreira CD, Antoniolli AR, Araújo CC 1999. Metodologia para avaliação de plantas com atividade no sistema nervoso central e alguns dados experimentais. Rev Bras Farm 80: 72-76.

Almeida RN, Navarro DS, Barbosa-Filho JM 2001. Plants with central analgesic activity. Phytomedicine $8: 310$ 322.

Asakura W, Matsumoto K, Ohta H, Watanbe H 1993. Effects of alpha 2-adrenergic drugs on REM sleep deprivationinduced increase in swimming activity. Pharmacol Biochem Behav 46: 111-115. 
Buchbauer G, Jäger W, Jirovetz L, Meyer F, Dietrich H 1992. Effects of valerian root oil, borneol, isoborneol, bornyl acetate and isobornyl acetate on the motility of laboratory animals (mice) after inhalation. Pharmazie 47: 620-622.

Carlini EA 2003. Plants and the central nervous system. Pharmacol Biochem Behav 75: 501-512.

De Sousa DP, Gonçalves JCR, Quintans-Júnior LJ, Cruz JS, Araújo DAM, Almeida RN 2006. Study of anticonvulsant effect of citronellol, a monoterpene alcohol, in rodents. Neurosci Lett 401: 231-235.

De Sousa DP, Quintans LJ, Almeida RN 2007. Evaluation of the anticonvulsant activity of alfa-terpineol. Pharm Biol 45: 69-70.

Gherlardini C, Galeotti N, Mazzanti G 2001. Local anaesthetic activity of monoterpenes and phenylpropanes of essential oils. Planta Med 67: 564-566.

File SE, Pellow S 1986. Intrinsic actions of the benzodiazepine receptor antagonist Ro 15-1788. Psychopharmacol 88: $1-11$.

Guimarães AG, Oliveira GF, Melo MS, Cavalcanti SCH, Antoniolli AR, Bonjardim LR, Silva FA, Santos JPA, Rocha RF, Moreira JCF, Araújo AAS, Gelain DP, Quintans-Júnior LJ 2010. Bioassay-guided evaluation of antioxidant and antinociceptive activities of carvacrol. Basic Clin Pharmacol Toxicol 107: 949957.

Leite MP, Fassin Jr J, Baziloni EMF, Almeida RN, Mattei R, Leite JR 2008. Behavioral effects of essential oil of Citrus aurantium L. inhalation in rats. Rev Bras Farmacogn 18: 661-666.

Lenardão EJ, Botteselle GV, Azambuja F, Perin G, Jacob RG 2007. Citronellal as key compound in organic synthesis. Tetrahedron 63: 6671-6712.

Lehmann J, Hutchison A, McPherson SE, Mondadori C, Schmutz M, Sinton CM, Tsai C, Murphy DE, Steel DJ, Williams M, Cheney DL, Wood PL 1988. CGS 19755 a selective and competitive $N$-Metil-D-aspartatetype excitatory amino acid receptor antagonist. $J$ Pharmacol Exp Ther 246: 65-75.

Löscher W 1998. New visions in the pharmacology of anticonvulsion. Eur J Pharmacol 342: 1-13.

Löscher W, Schmidt D 2006. New horizons in the development of antiepileptic drugs: Innovative strategies. Epilepsy Res 69: 183-272.

Melo MS, Sena LCS, Barreto FJN, Bonjardim L, Almeida JRGS, Lima JT, De Sousa DP, Quintans-Júnior LJ 2010. Antinociceptive effect of citronellal in mice. Pharm Biol 48: 411-416.

Morais LCSL, Quintans-Júnior LJ, Franco CIF, Almeida JRGS, Almeida RN 2004. Antiparkinsonian-like effects of Plumbago scandens on tremorine-induced tremors methodology. Pharmacol Biochem Behav 79: 745-749.

Netto SM, Warela RWB, Fechine MF, Queiroga MN, QuintansJúnior LJ 2009. Anxiolytic-like effect of Rauvolfia ligustrina Willd. Ex Roem. \& Schult. Apocynaceae, in the elevated plus-maze and hole-board tests. Rev Bras Farmacogn 19: 888-892.

Nicoll RA 2001. Introduction to the pharmacology of the central nervous system (CNS). In Katzung BG (ed.)
Basic and Clinical Pharmacology, 8. ed. New York: McGraw-Hill, p. 351-363.

Ngo Bum E, Schmutz M, Meyer C, Rakotonirina A, Bopelet M, Portet C, Jeker A, Rakotonirina SV, Olpe HR, Herrling P 2001. Anticonvulsant properties of the methanolic extract of Cyperus articulatus (Cyperaceae). J Ethnopharmacol 76: 145-150.

Olayiwola G, Obafemi CA, Taiwo FO 2007. Synthesis and neuropharmacological activity of some quinoxalinone deriv African. J Biotechnol 6: 777-786.

Oliveira FA, Almeida RN, Sousa MFV, Barbosa-Filho JM, Diniz SA, Medeiros IA 2001. Anticonvulsant properties of $N$-salicyloyltryptamine in mice. Pharmacol Biochem Behav 68: 199-202.

Passos CS, Arbo MD, Rates SMK, Von Poser GL 2009. Terpenóides com atividade sobre o Sistema Nervoso Central (SNC). Rev Bras Farmacogn 19: 140-149.

Perez GRM, Perez LJA, Garcia DLM, Sossa MH 1998. Neuropharmacological activity of Solanum nigrum fruit. J Ethnopharmacol 62: 43-48.

Pedersen ME, Vestergaard HT, Hansen SL, Bah S, Diallo D, Jäger AK 2009. Pharmacological screening of Malian medicinal plants used against epilepsy and convulsions. J Ethnopharmacol 121: 472-475.

Quintans-Júnior LJ, Almeida JRGS, Lima JT, Nunes XP, Siqueira JS, Oliveira LEG, Almeida RN, AthaydeFilho PF, Barbosa-Filho JM 2008a. Plants with anticonvulsant properties: a review. Rev Bras Farmacogn 18: 798-819.

Quintans-Júnior LJ, Souza TT, Leite BS, Lessa NMN, Bonjardim LR, Santos MRV, Alves PB, Blank AF, Antoniolli AR 2008b. Phythochemical screening and anticonvulsant activity of Cymbopogon winterianus Jowitt (Poaceae) leaf essential oil in rodents. Phytomedicine 15: 619-624.

Quintans-Júnior LJ, Melo MS, De Sousa DP, Araújo AAS, Onofre ACS, Gelain DP, Gonçalves JCR, Araújo DAM, Almeida JRGS, Bonjardim LR 2010a. Antinociceptive activity of citronellal in formalin-, capsaicin- and glutamate-induced orofacial pain in rodents and its action on nerve excitability. $J$ Orofac Pain 24: 305-312.

Quintans-Júnior LJ, Siqueira JS, Melo MS, Silva DA, Morais LCSL, Souza MFV, Almeida RN 2010b. Anticonvulsant evaluation of Rauvolfia ligustrina Willd. ex Roem. \& Schult., Apocynaceae, in rodents. Rev Bras Farmacogn 20: 54-59.

Quintans-Júnior LJ, Rocha RF, Caregnato FF, Moreira JCF, Silva FA, Araujo AAS, Santos JPA, Melo MS, De Sousa DP, Bonjardim LR, Gelain DP 2011. Antinociceptive action and redox properties of citronellal, an essential oil present in lemon grass. $J$ Med Food, DOI: 10.1089=jmf.2010.0125.

Silva MIG, Aquino Neto MR, Teixeira Neto PF, Moura BA, Amaral JF, De Sousa DP, Vasconcelos SMM, De Sousa FCF 2007. Central nervous system activity of acute administration of isopulegol in mice. Pharmaco Biochem Behav 88: 141-147.

Silva MAG, Aquino Neto MR, Moura BA, Sousa HL, Lavor EPH, Vasconcelos PF, Macêdo DS, De Sousa DP, Vasconcelos SMM, Sousa FCF 2009. Effects of 
isopulegol on pentylenetetrazol-induced convulsions in mice: Possible involvement of GABAergic system and antioxidant activity. Fitoterapia 80: 506-513.

Smith M, Wilcox KS, White HS 2007. Discovery of antiepileptic drugs. Neurotherapeutics 4: 12-17.

Tortoriello J, Ortega A 1993. Sedative effect of galphimine B, a nor-seco-triterpenoid from Galphimia galuca. Planta Med 59: 398-400.

\section{*Correspondence}

Lucindo J. Quintans-Júnior

Departamento de Fisiologia, Universidade Federal de Sergipe

Av. Marechal Rondom s/n, São Cristóvão-SE, Brazil lucindo@ufs.br; lucindo@pq.cnpq.br

Tel. +557921056645

Fax: +557932126640 